\title{
ISBAT NIKAH MELEGALKAN PERNIKAHAN SIRRI MENURUT HUKUM POSITIF DAN HUKUM AGAMA (STUDI DI PENGADILAN AGAMA PALANGKA RAYA)
}

\author{
SANAWIAH \\ Dosen Program Studi Al Ahwal Al Syakhsyiyah Fakultas Agama Islam \\ Universitas Muhammadiyah Palangkaraya \\ Email : sanaw10@yahoo.co.id
}

\begin{abstract}
The purpose of this study was to find out what sirri marriage laws according to Islamic Law and Positive Law, to find harmony and marriage requirements and to find out how the role of Religious Court of Palangka Raya in socialization confirmation marriage.

The method used in this research is the method of legal normative. As for the type of research used in this study is inventory regulations that related to confirmation of marriage legalized marriage sirri according to Positive Law and Religious Law.

Law wedding sirri results according to Islamic Law and Positive Law, sirri marriage according to Islamic Law illegitimate because it does not have a guardian of marriage, while marriage sirri in the view of the majority of Indonesian society is marriage not recorded but the terms and illegitimate pillars have been met in accordance with Islamic Law. Meanwhile, according to the law of the wedding positive sirri is as where according to Marriage Law in Indonesia if a legal marriage in syar'i then legitimate also according to law "marriage is not recorded" is legal according to the laws and regulations because according to Islamic Marriage Law applicable in Indonesia is based on Article 2 (1) of Law No. 1 of 1974 in conjunction with Article 4 Compilation of Islamic Law (as ius constitutun) in conjunction with Article 3 bill-HM-PA-Bperkw 2007 (as ius constituendum).
\end{abstract}

Keywords: confirmation, marriage, sirri and legal

\section{ABSTRAK}

Tujuan penelitian ini adalah untuk mengetahui apa hukum pernikahan sirri menurut Hukum Islam dan Hukum Positif, untuk mengetahui rukun dan syarat perkawinan dan untuk mengetahui bagaimana peranan Pengadilan Agama Palangka Raya dalam sosialisasi isbat nikah.

Metode yang digunakan dalam penelitian ini adalah metode hukum normatif. Adapun tipe penelitian yang digunakan dalam penelitian ini adalah inverintarisasi peraturan yang berkaitan dengan isbat nikah melegalkan pernikahan sirri menurut Hukum Positif dan Hukum Agama.

Hasil hukum pernikahan sirri menurut Hukum Islam dan Hukum Positif, menurut Hukum Islam pernikahan sirri tidak sah karena tidak memiliki wali nikah, sedangkan nikah sirri menurut pandangan sebagian besar masyarakat indonesia adalah pernikahan yang tidak tercatat tetapi syarat dan rukun nikahnya sudah terpenuhi sesuai dengan syariat Islam. Sedangkan menurut Hukum Positif pernikahan sirri adalah sebagaimana menurut Undang-Undang Perkawinan di Indonesia jika perkawinan sah secara syar'i maka sah pula menurut perundang-undangan. "Perkawinan tidak dicatat" adalah sah menurut peraturan perundang-undangan karena sesuai dengan Hukum Perkawinan Islam yang berlaku di Indonesia berdasarkan Pasal 2 ayat (1) Undang-Undang Nomor 1 Tahun 1974 juncto Pasal 4 Kompilasi Hukum Islam (sebagai ius constitutun), juncto Pasal 3 RUU-HM-PA-Bperkw Tahun 2007 (sebagai ius constituendum).

Kata kunci : isbat, nikah, sirri dan legal 


\section{PENDAHULUAN}

Perkawinan adalah salah satu asas pokok hidup, terutama dalam pergaulan atau bermasyarakat yang sempurna, selain itu perkawinan juga merupakan suatu pokok yang utama untuk menyusun masyarakat kecil, yang nantinya akan menjadi anggota dalam masyarakat yang besar.

Perkawinan merupakan perbuatan hukum, tujuan utama pengaturan hukum dalam perkawinan adalah upaya untuk mewujudkan rumah tangga yang sakinah, mawaddah dan rahmah serta menghindari potensi penzaliman antara satu pihak dengan pihak lainnya. Kenyataan di masyarakat masih banyak ditemukan perkawinan yang dilakukan pasca berlakunya Undang-Undang Nomor 1 Tahun 1974 yang tidak dicatatkan pada Pegawai Pencatat Nikah Kantor Urusan Agama dengan berbagai sebab dan alasan sehingga mereka tidak mempunyai Buku Nikah.

Hukum Islam dan Hukum Positif mempunyai upaya yang sama dalam hal kebijakannya, dimana Hukum Islam bisa berubah sesuai dengan keadaan zaman dengan syarat perubahan itu tidak bertentangan dengan AlQur'an dan Hadits, terutama yang ramai sekarang ini dibicarakan mengenai pernikahan sirri, dan peraturan baru mengenai perkawinan dianggap tidak sah kalau tidak tercatat, hal ini sesuai dengan Al Qur'an yang diqiyaskan kepada pencatatan kegiatan mudayanah yang dalam situasi tertentu diperintahkan agar dicatat. Firman Allah QS. Al-Baqarah ayat 282, artinya : Hai orang-orang yang beriman, apabila kamu bermu'amalah tidak secara tunai untuk waktu yang ditentukan, hendaklah kamu menuliskannya... (QS. Al-Baqarah 282). Begitu juga ada lagi ayat al Al-Quran dalam Surah An Nisa (4) ayat 21, salah satu bunyi ayatnya yang menerangkan tentang Ikatan yang kuat (bukti tertulis) dan menulis dalam bentuk akta nikah yang dikeluarkan KUA (Kantor Urusan Agama) tujunnya untuk kemaslahatan umat Islam, karena kalau tidak tercatat akan banyak membawa kemudharatan, hak-hak istri dan anak terabaikan tidak dapat menuntut ketika terjadi pembagian warisan dan lain sebagainya. Oleh karena itu pencatan pernikahan masuk ke dalam salah satu rukun pernikahan, karena kalau tidak tercatat menurut Hukum Islam dan Hukum Positif tidak sah pernikahannya.

Rukun adalah unsur yang melekat pada peristiwa hukum atau perbuatan hukum (misal akad perkawinan), baik dari segi subjek hukum maupun obyek hukum yang merupakan bagian dari perbuatan hukum tersebut berlangsung. Rukun menentukan sah atau tidaknya sesuatu perbuatan peristiwa hukum. Jika salah satu rukun dalam peristiwa atau perbuatan hukum itu tidak terpenuhi berakibat perbuatan hukum atau peristiwa hukum tersebut itu adalah tidak sah dan statusnya "batal demi hukum" demikian pula menurut ulama fiqih, bahwa rukun berfungsi menentukan sah atau batalnya perbuatan hukum. Suatu perbuatan atau tindakan hukum dinyatakan sah jika terpenuhi seluruh rukunnya, dan perbuatan hukum itu dinyatakan tidak sah jika tidak terpenuhi salah satu atau lebih atau semua rukunnya (Abdul Azis Dahlan, 2000).

Undang-Undang Nomor 1 Tahun 1974 tentang Perkawinan pada Pasal 2 ayat (2) menyebutkan bahwa tiap-tiap perkawinan dicatat menurut peraturan perundang-undangan yang 
berlaku. Pencatatan perkawinan akan menimbulkan kemaslahatan umum karena dengan pencatatan ini akan memberikan kepastian hukum terkait dengan hak-hak suami/isteri, kemaslahatan anak maupun efek lain dari perkawinan itu sendiri. Perkawinan yang dilakukan di bawah pengawasan atau di hadapan Pegawai Pencatat Nikah Kantor Urusan Agama akan mendapatkan Akta Nikah sebagai bukti telah dilangsungkannya sebuah perkawinan.

Kompilasi Hukum Islam juga memberikan rumusan tentang perkawinan yang sah dan ketentuan untuk tertibnya perkawinan. Pasal 4 Kompilasi Hukum Islam memberikan penegasan bahwa "perkawinan adalah sah apabila dilakukan menurut Hukum Islam sesuai dengan pasal 2 ayat 1 UU No. 1 tahun1974 tentang Perkawinan. Pasal $5 \mathrm{KHI}$ merumuskan: (1) agar terjamin ketertiban perkawinan bagi masyarakat Islam setiap perkawinan harus dicatat; (2) pencatatan perkawinan tersebut pada ayat (1), dilakukan oleh Pegawai Pencatat Nikah sebagaimana yang diatur dalam Undang-Undang No. 22 Tahun 1946 jo Undang-Undang No. 32 Tahun 1954. Selanjutnya Pasal 6 KHI merumuskan: (1) untuk memenuhi ketentuan dalam pasal 5 , setiap perkawinan harus dilangsungkan di hadapan dan di bawah pengawasan Pegawai Pencatat Nikah; (2) perkawinan yang dilakukan di luar pengawasan Pegawai Pencatat Nikah tidak mempunyai kekuatan hukum. Pasal 7 menyebutkan bahwa: (1) perkawinan hanya dapat dibuktikan dengan Akta Nikah yang dibuat oleh Pegawai Pencatat Nikah; (2) dalam hal perkawinan tidak dapat dibuktikan dengan Akad Nikah, dapat diajukan isbat nikahnya ke Pengadilan Agama; (3) isbat nikah yang dapat diajukan ke Pengadilan Agama terbatas mengenai hal-hal yang berkenaan dengan : (a) adanya perkawinan dalam rangka penyelesaian perceraian; (b) hilangnya Akta Nikah; (c) adanya keraguan tentang sah atau tidaknya salah satu syarat perkawinan; (d) adanya perkawinan yang terjadi sebelum berlakunya Undang-undang No. 1 Tahun 1974 dan; (e) perkawinan yang dilakukan oleh mereka yang tidak mempunyai halangan perkawinan menurut Undang-Undang No.1 Tahun 1974; (4) yang berhak mengajukan permohonan isbat nikah ialah suami atau isteri, anak-anak mereka, wali nikah dan pihak yang berkepentingan dengan perkawinan itu.

Masyarakat Kalimantan Tengah khususnya di Palangka Raya, belum banyak yang mengerti, mengenal apa isbat nikah, selama ini suami istri yang sudah menikah puluhan tahun menikah sirri atau nikah menurut agama, dan tidak tercatat sudah memiliki anak cucu, mereka berbondongbondong ikut nikah massal, mereka ingin pernikahannya tercatat, ketika ada pengumuman akan dilaksanakan pernikahan massal, baik yang diselenggarakan oleh instansi pemerintah, swasta maupun organisasi kemasyarakatan (ormas).

Setelah penulis mengamati dan seringnya ikut mengadakan pernikahan massal, untuk membantu masyarakat yang belum memiliki akta nikah, ternyata ada masalah dibalik pernikahan massal, yaitu tentang status anak yang sudah lama lahir, tidak termasuk anak kandung ketika meminta Akte Kelahiran di Dukcapil, karena yang diakuai hanya anak setelah pernikan atau surat nikah terbit setelah pernikahan, dan kesalah pahaman masyarakat tentang perkawinan sirri. 
Permasalahan yang menyangkut hal ini dapat dirumuskan berupa: 1). apa hukum pernikahan sirri menurut Hukum Islam dan Hukum Positif?, 2). apa rukun dan syarat perkawinan?; dan 3). bagaimana peranan Pengadilan Agama Palangka Raya dalam sosialisasi isbat nikah?

Tujuan dan manfaat penelitian ini diharapkan untuk mengetahui: 1) apa hukum pernikahan sirri menurut Hukum Islam dan Hukum Positif; 2). rukun dan syarat perkawinan; dan 3) bagaimana peranan Pengadilan Agama Palangka Raya dalam sosialisasi isbat nikah.

Gambaran pernikahan dan kebutuhan hukumnya inilah menjadi penting penting sebuah penelitian tentang isbat nikah melegalkan pernikahan sirri menurut Hukum Positif dan Hukum Agama yang dilakukan dengan cara studi di Pengadilan Agama Palangka Raya.

\section{A. Isbat Nikah \\ Pengertian Isbat Nikah}

Isbat berasal dari Bahasa Arab atsbatayutsbitu-isbatan yang artinya adalah penguatan. Sedang dalam kamus ilmiah populer kata itsbat diartikan sebagai memutuskan atau menetapkan. Sedang nikah dalam kamus hukum diartikan sebagai akad yang memberikan faedah untuk melakukan mut'ah secara sengaja, kehalalan seorang laki laki untuk beristimta' dengan seorang wanita selama tidak ada faktor yang menghalangi sahnya pernikahan tersebut secara syar'i (Pius A Partanto dan M. Dahlan Al Barry, 1994: 273).

Sedangkan menurut bahasa isbat nikah terdiri dari dua kata yaitu kata "itsbat" yang merupakan masdar atau asal kata dari "atsbata" yang memiliki arti "menetapkan", dan kata "nikah" yang berasal dari kata "nakaha" yang memiliki arti "saling menikah", dengan demikian kata "itsbat nikah" memiliki arti yaitu "penetapan pernikahan". (Ahmad Warsono Munawir, 145).

Menurut Peter Salim kata itsbat nikah memiliki pengertian penetapan tentang kebenaran nikah. Itsbat nikah sebenarnya sudah menjadi istilah dalam Bahasa Indonesia dengan sedikit revisi yaitu dengan sebutan isbat nikah. Menurut Kamus Besar Bahasa Indonesia, isbat nikah adalah penetapan tentang kebenaran (keabsahan) nikah. Isbat nikah adalah pengesahan atas perkawinan yang telah dilangsungkan menurut syariat agama Islam, akan tetapi tidak dicatat oleh KUA atau PPN yang berwenang (Keputusan Ketua Mahkamah Agung RI Nomor KMA/032/SK/2006 tentang Pedoman Pelaksanaan Tugas dan Administrasi Pengadilan).

\section{Pengertian Perkawinan Tidak Dicatat}

Pengertian "perkawinan tidak dicatat" berbeda dengan "perkawinan sirr" yaitu "perkawinan tidak tercatat" adalah perkawinan yang memenuhi rukun dan syarat sesuai dengan Hukum Islam, tetapi tidak dicatatkan atau belum dicatatkan di Kantor Urusan Agama (KUA Kecamatan) sebagai Unit Pelaksana Teknis Dinas (UPTD) instansi pelaksana di wilayah Kecamatan setempat, sebagaimana ditentukan dalam Undang-undang Nomor 23 Tahun 2006 tentang Administrasi Kependudukan.

Istilah "tidak dicatat" tidak sama dengan istilah "tidak dicatatkan". Kedua istilah tersebut mengandung makna yang berbeda. Istilah "perkawinan tidak dicatat" bermakna bahwa perkawinan itu tidak mengandung unsur "dengan sengaja" yang mengiringi itikad atau niat seseorang untuk tidak mencatatkan 
perkawinannya memang "dengan segaja" tidak dicatatkan. "Perkawinan tidak dicatat" dengan "perkawinan yang belum dicatatkan" yang berbeda dengan perkawinan tidak dicatatkan (Neng Djubaidah, 154).

\section{METODOLOGI}

Metode penelitian ini menggunakan menggukan jenis penelitian hukum normatif (legal research). Tipe penelitian yang digunakan dalam penelitian ini adalah inverintarisasi peraturan yang berkaitan dengan isbat nikah melegalkan pernikahan sirri menurut Hukum Positif dan Hukum Agama.

\section{HASIL DAN PEMBAHASAN}

\section{A. Hukum Pernikahan Sirri Menurut Hukum Islam dan Hukum Positif}

Hukum Nikah Sirri Menurut Islam

Pendapat Imam Abu Hanifah, yang dimaksud dengan nikah sirri adalah nikah yang tidak bisa menghadirkan wali dan tidak mencatatkan pernikahannya ke KUA dengan tiga imam madzab lainnya. Beliau menetapkan bahwa wanita yang telah baligh dan berakal (dalam kondisi normal) maka diperbolehkan memilih sendiri calon suaminya. Dia tidak hanya tergantung pada walinya saja. Lebih lanjut beliau menjelaskan wanita baligh dan berakal juga diperbolehkan aqad nikah sendiri baik dalam kondisi perawan atau janda (Rofei: 145).

Sedangkan menurut Kiyai Hisen Muhamad seorang komisioner Komnas Perempuan menyatakan pernikahan pria dewasa dengan wanita secara sirri merupakan pernikahan terlarang karena pernikahan tersebut dapat merugikan si perempuan, sedangkan Islam justru melindungi perempuan bukan malah merugikannya.

Ibnu Taimiyah (dalam Rusman Yahya, 1997:202) menyampaikan tentang pertanyaan seseorang kepada Syaikhui Islam rahimakhumullah, yaitu mengenai seseorang lakilaki yang menikahi seorang perempuan dengan cara mushafahah atau nikah sirri, yaitu perkawinan tanpa wali dan tanpa saksi, dengan maskawin lima dinar, setiap tahun setengah dinar, dan ia telah tinggal bersamanya dan mencampurinya. Menurut Ibnu Taimiyah, Syaikhul Islam rahimakhumullah menjawab, bahwa laki-laki yang menikahi perempuan tanpa wali dan saksisaksi, serta merahasiakannya, menurut kesepakatan para Imam, perkawinan itu bathil Ibnu Taimiyah mengemukakan bahwa perkawinan sirri adalah sejenis perkawinan pelacur, karena tanpa wali dan tanpa dua saksi, dan perkawinan sirri juga termasuk dzawatil akhdan yaitu perempuan yang mempunyai laki-laki piaraan (gundik). Perbuatan tersebut adalah haram dilakukan.

Oleh karena itu, perkawinan sirri dalam arti perkawinan yang disembunyikan dan tidak terpenuhinya rukun dan syarat perkawinan berdasarkan Hukum Islam, adalah perkawinan yang tidak sah. Jika mereka tetap melanjutkan kehidupan perkawinannya, menurut Umar bin khattab, mereka termasuk melakukan zina, maka layak mendapat hukuman jilid (dera atau cambuk). Hadist tersebut diriwayatkan Syafi'i dan Daruquthni dari 'Ikimah bin Khulid.

Menurut pendapat Imam Malik, yang dimaksud dengan "perkawinan sirri" berdasarkan hadist dari Abi Zubair Al-Maliki, yang 
menyampaikan hadist Umar bin Khattab, adalah perkawinan yang hanya disaksikan oleh "seorang saksi laki-laki dan saksi perempuan". Menurut Umar bin Khatab, perkawinan tersebut adalah perkawinan sirri yang dilarang. Jika perkawinan itu dilanjutkan, maka Umar bin Khattab akan merajam pelaku perkawinan sirri tersebut. Sebagaiman kutipan langsung berikut: "ini perkawinan sirri, aku tidak memperkenankannya, dan kalau engkau tetap melakukannya tentu kurajam". Hadist dari Umar bin Khattab tersebut menunjukan bahwa perkawinan sirri adalah perkawinan yang tidak memenuhi rukun dan syarat perkawinan.

Hal nikah tanpa saksi, bahwa dalam hadist Rasulullah SAW, yang diriwayatkan Tarmizi dari Ibnu 'Abbass ra. Bahwa "sesungguhnya Nabi SAW, bersabda "perempuan-perempuan pelacur, yaitu mereka yang menikahkan diri mereka sendiri tanpa saksi". Oleh karena itulah, Ibnu Taimiyah mengemukakan bahwa perkawinan sirri adalah sejenis perkawinan pelacur, karena tanpa wali dan dua orang saksi, dan perkawinan sirri juga termasuk dzawatil akhdan, yaitu perempuan yang mempunyai laki-laki piaraan. Perbuatan tersebut adalah haram dilakukan berdasarkan surat AlMaaidah (5) ayat 5. Hukum perkawinan sirri adalah haram, karena perkawinan sirri adalah sama dengan samen leven atau kumpul kebo, tetapi kumpul kebo berbeda dengan pelacuran (Rusman Yahya, 1997:202).

\section{Nikah Sirri yang Dikenal Masyarakat Indonesia Pernikahan "yang Tidak Dicatat"}

Hukum nikah sirri secara agama adalah sah atau legal dan dihalalkan atau diperbolehkan jika sarat dan rukun nikanya terpenuhi pada saat ini nikah sirri digelar. Rukun nikah yaitu 1).
Adanya kedua mempelai, 2) adanya wali, 3) adanya saksi nikah, 4) adanya mahar atau mas kawin, 5) adanya ijab kabul atau akad.

Sedangkan pandangan para ulama tentang nikah sirri adalah menurut pandangan Madzhab Hanafi dan Hambali suatu penikahan yang sarat dan rukunnya maka sah menurut agama Islam walaupun pernikah itu adalah pernikahan sirri. Hal itu sesuai dengan dalil yang berbunyi dan artinya "takutlah kamu terhadap wanita, kamu ambil mereka (dari orang tuanya) dengan amanah Allah dan kamu halalkan percampuran kelamin dengan mereka dengan kalimat allah (ijab qabul') (rohil muslaim).

\section{Nikah Sirri Menurut Hukum Positif}

Sebagaimana telah dikemukakan bahwa "perkawinan tidak dicatat" adalah bebeda dengan "perkawianan sirri", karena yang dimaksud dengan "perkawinan tidak tercatat" ini adalah perkawinan yang memenuhi rukun dan syarat berdasarkan Hukum Islam. Menurut UndangUndang Perkawinan di Indonesia jika perkawinan sah secara syar'i maka sah pula menurut perundang-undangan. "Perkawinan tidak dicatat" adalah sah menurut peraturan perundangundangan karena sesuai dengan Hukum Perkawinan Islam yang berlaku di Indonesia berdasarkan Pasal 2 ayat (1) Undang-Undang Nomor 1 Tahun 1974 juncto Pasal 4 Kompilasi Hukum Islam (sebagai ius constitutun). Juncto Pasal 3 RUU-HM-PA-B Tahun 2007 (sebagai ius constituendum).

Berdasarkan kajian ini dapat dikemukakan bahwa" perkawinan tidak tercatat" sebagai perkawinan yang sah berdasarkan Hukum Islam, adalah sah pula menurut Pasal 2 ayat (1) Undang-Undang Nomor 1 tahun 1974. 
Perkawinan yang sah menurut agama juga dijamin UUD tahun 1945, dalam Pasal 29 ayat (1) dan ayat (2) juncto Pasal 28B ayat (1) Juncto Pasal 281.

Jika perkawinan yang sah menurut agama itu dinyatakan tidak mempunyai kekuatan hukum oleh karena belum dicatat, maka ketentuan "pencatatan perkawinan" telah melanggar hak asasi manusia Indonesia yang beragama Islam. Sahnya perkawianan bagi orang Islam di Indonesia, menurut pasal 2 RUU Perkawinan Tahun 1973, ditentukan berdasarkan "pencatatan perkawinan" sebagai insur penentu. Hukum agama (Islam) dapat diberlakukan sepanjang tidak bertentangan dengan undang-undang ini yang berfungsi sebagai pelengkap, bukan penentu.

\section{B. Rukun dan Syarat Perkawinan}

\section{Pengertian dan Rukun Syarat Perkawinan}

Membahas "pencatatan perkawinan dan perkawinan tidak tercatat" tidak dapat terlepas dari ketentuan-ketentuan rukun dan syarat perkawinan yang berlaku bagi orang Islam di Indonesia. Rukun dan syarat perkawinan dalam Hukum Islam merupakan hal penting, demi terujudnya suatu ikatan perkawinan antara seorang lelaki dengan seorang permpuan. Rukun perkawinan merupakan penentu bagi sahnya atau tidaknya suatu perkawinan. Adapun syarat perkawinan adalah faktor-faktor yang harus dipenuhi oleh subyek hukum yang merupakan unsur atau bagian dari akad nikah.

Asas-Asas Hukum Perkawinan Islam

a. Asas personalia kelslaman

b. Asas kesukarelaan

c. Asas persetujuan d. Hak kebebasan memilih pasangan

e. Asas kemitraan

f. Asas monogami terbuka

g. Asas untuk selama-lamanya

\section{Peranan Pengadilan Agama Palangka Raya Dalam Sosialisasi Isbat Nikah}

\section{Isbat Nikah Belum Dikenal Dalam Masyarakat}

Kementerian Agama (Kemenag) terus menyorot pertumbuhan perilaku nikah sirri alias tidak tercatat di Kantor Urusan Agama (KUA). Mereka meminta pasangan nikah sirri segera mengikuti isbat nikah. Sehingga hak-hak sipil pasangan dan anak-anaknya diakui pemerintah. Direktur Urusan Agama Islam dan Pembinaan Syariah (Dir Urais-Binsyar) Kemenag Muchtar Ali menuturkan, program isbat ini merupakan kerjasama antara Kemenag, Mahkamah Agung (MA), dan Kementerian Dalam Negeri (Kemendagri). "Perlu saya tegaskan bahwa isbat nikah ini sangat menguntungkan bagi masyarakat. Berbeda sekali dengan nikah atau kawin massal," tandasnya di Jakarta kemarin. Muchtar menuturkan ketentuan isbat nikah untuk pasangan nikah sirri berlaku surut.

Artinya jika saat isbat nikah pasangan sirri tadi sudah memiliki anak, otomatis anak tersebut bisa mendapatkan akta kelahiran dan hak-hak kependudukan lainnya. Sebaliknya prosesi nikah masal tidak berlaku surut. Jika ada pasangan sirri telah memiliki anak dan mengikuti nikah masal, negara tidak mengakui status anak tersebut. Maka anak-anak dari pasangan nikah sirri yang mengikuti kawin massal di KUA tidak berhak mendapatkan akta kelahiran. "Pemerintah perlahan akan menghapus praktek nikah massal untuk pasangan sirri" (Artelil, 2015). 


\section{Sebab-sebab Diajukannya Permohonan Isbat Nikah}

Isbat nikah yang dilaksanakan oleh Pengadilan Agama karena pertimbangan mashlahah bagi umat Islam. Isbat nikah sangat bermanfaat bagi umat Islam untuk mengurus dan mendapatkan hak-haknya yang berupa suratsurat atau dokumen pribadi yang dibutuhkan dari instansi yang berwenang serta memberikan jaminan perlindungan kepastian hukum terhadap masing-masing pasangan suami istri.

Sebab-sebab yang melatarbelakangi adanya permohonan isbat nikah ke PA itu sendiri, dalam praktek, khususnya di PA pihak-pihak yang mengajukan permohonan isbat nikah dapat ditemukan kebanyakannya (Departemen Agama RI: 167), yaitu:

1. Adanya perkawinan yang terjadi sebelum berlakunya UU No. 1 tahun 1974, untuk hal ini biasanya dilatarbelakangi:

a. Guna untuk mencairkan dana pensiun pada PT. Taspen;

b. Untuk penetapan ahli waris dan pembagian harta waris.

2. Adanya perkawinan yang terjadi sesudah berlakunya UU No. 1 tahun 1974, ini biasanya dilatarbelakangi oleh karena akta nikah hilang (bisa karena untuk pembuatan Akta Kelahiran Anak, bisa juga digunakan untuk gugat cerai, atau bisa juga untuk gugat pembagian harta gono-gini). Untuk kasus akta nikah hilang seperti ini, biasanya pihak pemohon dianjurkan untuk memintakan duplikat kutipan akta nikah dimana tempat nikahnya itu dilaksanakan; tapi kadangkala ditemukan juga pihak KUA menerangkan perkawinannya tidak terdaftar di KUA.
Setelah hadirnya UU yang mengatur tentang isbat nikah, mengapa isbat nikah tidak terlalu dikenal masyarakat terutama di Kalimantan Tengah khususnya di Palangka Raya adalah menurut salah seorang Panitera Pengadilan Agama Palangka Raya (PA) atas nama $\mathrm{Nr}$, kendala yang di hadapi PA untuk mengisbatkan nikah terutama yang nikah tidak tercatat atau istilah masyarakat kita nikah sirri dibawah tahun 1974 yang pertama mengenai susahnya membuktikan wali, saksi-saksi, karena rata-rata wali dan saksi si pemohon isbat nikah sudah meninggal dunia, akhirnya pengadilan agama tidak mengabulkan permintaan pemohon karena PA tidak boleh memputus perkara tanpa aturan syarat dan rukun yang tidak jelas. Menurut beliau, karena banyaknya kendala ini masyarakat akhirnya mengambil jalan pintas yaitu ikut nikah massal.

\section{KESIMPULAN DAN SARAN}

\section{Kesimpulan}

1. Hukum pernikahan sirri menurut Hukum Islam dan Hukum Positif, yaitu menurut Hukum Islam pernikahan sirri tidak sah karena tidak memiliki wali nikah, sedangkan nikah sirri menurut pandangan sebagian besar masyarakat indonesia adalah pernikahan yang tidak tercatat tetapi syarat dan rukun nikahnya sudah terpenuhi sesuai dengan Syariat Islam. Sedangkan menurut Hukum Positif pernikahan sirri adalah sebagaimana menurut UndangUndang Perkawinan di Indonesia jika perkawinan sah secara syar'i maka sah pula menurut perundang-undangan. "Perkawinan tidak dicatat" adalah sah menurut peraturan 
perundang-undangan karena sesuai dengan Hukum Perkawinan Islam yang berlaku di Indonesia berdasarkan Pasal 2 ayat (1) Undang-Undang Nomor 1 Tahun 1974 juncto Pasal 4 Kompilasi Hukum Islam (sebagai ius constitutun). Juncto Pasal 3 RUU-HM-PABperkw Tahun 2007 (sebagai ius constituendum). Perkawianan tidak dicatat yaitu perkawinan yang sah menurut Hukum Islam, yang dilakukan atas ibadah untuk menjalankan ketentuan Allah dan Rasul-Nya, tetapi belum dicatatkan, merupakan perbuatan yang "tidak mempunyai kekuatan hukum", atau perbuatan yang "lemah hukum" dan tidak dijamin oleh hukum.

2. Rukun dan syarat perkawinan, yaitu rukun aqad ada tiga berupa orang yang beraqad (subyek hukum), hal yang diakadkan (mu'qad'alah), dan sigah yaitu ijab dan kabul. Demikian pula dengan hal perkawinan, orang yang berakad adalah suami dan wali calon istri, yang diakadkan atau objek akad nikah halalnya hubungan antara suami istri secara timbal balik atau kemitraan, dan sigah adalah ijab dan kabul.

3. Peranan Pengadilan Agama Palangka Raya dalam sosialisasi isbat nikah. Menurut pihak pengadilan agama Palangka Raya, kendala yang dihadapi saat ini belum adanya aggaran untuk sosialisai ke masyarakat luas, sedangkan dalam melaksanakan pelayanan sudah dilakukan dengan baik dan memberikan penjelasan ketika ada masyarakat yang menanyakan syarat dan proses isbat nikah.

\section{Saran}

1. Untuk masyarakat muslim yang akan melangsungkan pernikahan harus benar-benar diniatkan ibadah karena Allah SWT dan mengikuti aturan Allah dan rasulnya serta aturan hukum pernikahan Islam di Indonesia, agar tidak terjadi kerugian baik pihak perempuan maupun anak.

2. Untuk pihak KUA syarat dan rukun perkawinan harus disampaikan kepada calon dan keluarga yang akan melangsungkan pernikahan.

3. Kepada pihak Pengadilan Agama sosialisasi mengenai isbat nikah terus dilakukan kepada masyarakat dan lebih baik lagi kerjasama dengan organisasi kemasyarakatan Islam (ormas-ormas Islam).

\section{DAFTAR PUSTAKA}

Abdul Aziz Dahian. 2000. Ensiklopedia Hukum Islam, Ichtiar Baru Van Hoeve.

Ahmad Warsono Munawir, Al-Munawir Kamus Arab-Indonesia.

Al Quran dan Terjemahan, Kementerian Agama Republik Indonesia.

Artelil. 2015. Anjurkan Pasangan Siri Untuk Isbat Nikah Mulai Hapus Program Nikah Massal, Kementerian Agama. diakses Senin 3 Agustus 2015.

Departemen Pendidikan dan Kebudayaan, Kamus Besar Bahasa Indonesia.

Neng Djubaidah. 2010. Pencatatan Perkawinan dan Perkawinan Tidak dicatat, Menurut Hukum Tertulis di Indonesia dan Hukum Islam. Jakarta : Sinar Grafika.

Pius A Partanto dan M. Dahlan Al Barry. 1994. Kamus IImiah Populer, Surabaya: Akola. 
Rofei. Artikel "Hukum Nikah Siri Menurut Perspektif Hukum Islam dan Hukum Positif Indonesia".

Rusman Yahya. 1997. Imam Al-Alamah Taqiyuddin Ibnu Taimiyah, Hukum -Hukum Perkawinan (Ahkamuz-Zawaaj), terjemahan oleh Rusman Yahya, Jakarta: Pustaka AlKautsar. 